\title{
DEL YERMO AL ALTAR. NOTICIA DE LOS MERCEDARIOS CALZADOS GRANADINOS Y DE LA BEATA MARÍA DE SANTA ROSA
}

\author{
POR \\ ANTONio Ceballos GuerRero ${ }^{1}$ \\ Biblioteca de Andalucía. Técnico de Patrimonio Bibliográfico
}

\begin{abstract}
RESUMEN
El trabajo que presentamos facilita noticia sobre los orígenes de la Orden de la Merced Calzada en Granada, de su presencia antigua e instalación conventual. Hemos centrado el interés principal en la presencia femenina en torno a los mercedarios granadinos y al beaterio que fundaron, partiendo de un grupo de beatas libres de sujeción a regla. De singular interés resulta la figura de una de ellas, la ermitaña María de Santa Rosa, popularmente conocida como la "santa de Sierra Elvira». Sobre su figura recayó un proyecto de santidad frustrado, con fines fundacionales. De este propósito mercedario solo perduró una tradición que se mantuvo hasta el siglo XX.
\end{abstract}

PALABRAS CLAVE: Orden de Nuestra Señora de la Merced Redención de Cautivos; Granada; convento; beaterio; beatas; ermitaña, María de Santa Rosa; santa de Sierra Elvira.

\section{FROM THE WILDERNESS TO THE ALTAR. NEWS OF MERCEDARIAN FOOTWEAR FROM GRANADA AND BEATA MARÍA DE SANTA ROSA}

\begin{abstract}
This work presents news about the origins of the Religious Order of Merced Calzada in Granada, its ancient presence and conventual establishment. We have focused the main interest in the female presence around the Mercedarians from Granada and the beaterio they founded, based on a group of free women who are subject to rule. Of singular interest is the figure of one of them, the hermit María de Santa Rosa, popularly known as the Saint of Sierra Elvira. Her figure supported a project of frustrated holiness, with foundational purposes. From this Mercedarian purpose only a tradition until the 20th century lasted.
\end{abstract}

KEY WORDS: Order of Our Lady of Mercy Redemption of Captives; Granada; convents; beaterios, beatas, hermits; María de Santa Rosa; Saint of Sierra Elvira.

Cómo CITAR ESTE ARTículo / CITATION: Ceballos Guerrero, Antonio. 2020. «Del yermo al altar. Noticia de los Mercedarios Calzados granadinos y de la beata María de Santa Rosa». Hispania Sacra LXXII, 145: 267-278. https://doi.org/10.3989/hs.2020.020

$\begin{array}{ll}\text { Recibido/Received } & 12-11-2018 \\ \text { Aceptado/Accepted } & 08-01-2019\end{array}$

\section{INTRODUCCIÓN}

Don Antonio Gallego Burín, en su Guía de Granada², refiere la existencia de diversos festejos, romerías y costumbres que por entonces se conservaban en poblaciones cercanas a Granada. Uno de ellos era la santa ermitaña Rosa, en Sierra Elvira. El trabajo que presentamos es el resultado

1 antonio.ceballos@juntadeandalucia.es / ORCID iD: https://orcid.org/0000-0001-8816-6096

2 Gallego Burín 1982, 35 de nuestra indagación sobre su figura, un resultado que, en nuestra opinión, ejemplifica en Granada varios conceptos de actualidad en la historiografía de la religiosidad en la Edad Moderna.

Resulta bien conocida para los historiadores la complejidad de la religiosidad femenina postridentina, más aún la del mundo de las beatas y de los beaterios, por su propia naturaleza. Este grupo heterogéneo de mujeres constituyó un contingente importante dentro del estamento religioso y, en muchas ocasiones, fueron utilizadas como ariete fundacional de las órdenes religiosas, especialmente por parte de descal- 
zos y recoletos. Granada no fue ajena a esta corriente de religiosidad, pues en su seno se ubicaron beaterios de diversa índole de los que tenemos noticias más o menos precisas. ${ }^{3}$

Uno de ellos fue el que surgió al calor del convento de los mercedarios calzados. Este beaterio sigue en sus orígenes pautas muy semejantes a otros que se fueron instituyendo a lo largo del siglo XVI. Durante este siglo, y el siguiente, florecieron multitud de formas religiosas, algunas de ellas bordeando la línea roja de la ortodoxia católica. La beata libre, la socialmente emancipada, la transgresora, la pícara, y todas las formas satélites de estos conceptos, existieron, aunque, en nuestra opinión, fueron muchas más las que vivieron una religiosidad personal, en gran medida por carecer de opciones para tomar estado de monja. ${ }^{4}$ De hecho, bien sea por autoprotección ante la contradictoria opinión social que su estado tenía asociado, bien por convencimiento, muchas de ellas buscaron la seguridad en la sujeción a una regla que practicase algún convento masculino cercano.

3 Para el caso de Granada, sin ánimo de agotar la nómina, podemos apuntar que en 1523 se fundó el convento de la Concepción, partiendo de un grupo de beatas terciarias franciscanas. Al año siguiente se fundaba un beaterio que sería el embrión del futuro convento de la Encarnación. En 1538 fue un grupo de terciarias franciscanas el que daría lugar al convento de Nuestra Señora de los Ángeles. En 1572 otro grupo de beatas, siguiendo la Regla de Santa Clara, implementarían el convento de santa Inés. Otros beaterios que también darían como resultado fundaciones fueron el de las capuchinas de Nuestra Señora de la Presentación; los de agustinas recoletas de Corpus Christi (1655) y Santo Tomás de Villanueva (1676). En la misma obra que citamos de Gallego Burín encontramos noticia del más conocido beaterio granadino, el de Santa María Egipciaca, así como del Beaterio del Santísimo, ambos con más vocación social que religiosa. También Francisco Henríquez de Jorquera en sus Anales da cuenta del primero de ellos, así como de los que estuvieron situados en el Campo de los Mártires, los denominados de Melchoras y Potencianas, ligados a la Orden Carmelita Descalza, que en 1683 se transformaría en el convento cisterciense de San Bernardo. De su existencia encontramos noticias más abundantes en la Gazetilla Curiosa del padre Lachica Benavides (papel XX), donde también figuran el que se fundó al aliento de los agustinos recoletos (las popularmente conocidas como Tomasas, Papel XXIV) y el que fundó doña Lucía de Ureña, que posteriormente sería de capuchinas descalzas (Papel XXXIX). El beaterio de agustinas recoletas ha sido estudiado in extenso en Ceballos Guerrero 2016, consultable en http://hdl.handle.net/10481/42411. Sobre la misma institución ver también Ceballos 2015, 145-168. Para un mejor conocimiento de la única institución de este tipo que consintió fundar bajo su prelacía el arzobispo don Pedro de Castro, la Casa de Madres Recogidas de Santa María Egipciaca, ver Medina Conde Herrera 1760. Recientemente ha aparecido un trabajo sobre el beaterio de Santa Catalina de Sena de Granada: García Valverde 2017, 269-289. Un resumen cumplido, en lo referente a fundaciones de las órdenes descalzas para la Granada del siglo XVII, se puede encontrar en López-Guadalupe Muñoz 2015.

El mundo de las beatas, quizá por la escasez de documentación y de estudios particulares, se ha conocido más por los casos transgresores o escatológicos (confundidas con visionarias, profetisas, adivinadoras, curanderas, etc.) fruto de las causas inquisitoriales instruidas. Ahora bien, los datos muestran lo contrario, de los miembros del clero condenados por el Santo Oficio en el Reino de Granada a lo largo del siglo XVII (137), solo 4 fueron beatas (Fernández García 1989). No obstante, es innegable que este colectivo acogía una variedad heterogénea en sus componentes. Un ejemplo que ha despertado nuestra curiosidad es el de Catalina de San Pedro Nolasco, que tomó el hábito de tercera mercedaria en Trujillo en 1720 siendo casada. Estos casos, de los que conocemos algún otro, suelen ocultar una realidad social discriminatoria para la mujer, apuntando a los malos tratos conyugales, porque, por ejemplo, Catalina «mientras estuvo casada tuvo mucho que sufrir con su marido» (Vidas de algunas personas... M-BN, Mss. 3456).
Por otra parte, este era un mecanismo fundacional bastante común de las distintas órdenes. La estrategia por parte del convento masculino consistía en la captación de mujeres que se sujetasen a su regla y, consecuentemente, vistieran su hábito. En numerosos casos, estas mujeres practicaban una religiosidad individual o se habían agrupado de forma libre. La labor de institucionalización femenina había intensificado sus esfuerzos desde el Concilio de Trento, utilizando como instrumentos eficaces a los predicadores, y especialmente los confesores, que ejercían una influencia decisiva en las conciencias. ${ }^{5}$ El mecanismo dio resultado en algunas ocasiones (ver nota 3) y fracasó en otras muchas. La nómina de fundaciones que no llegaron a realizarse por los más diversos motivos es abundante, al igual que lo fueron aquellas otras de vida efímera. ${ }^{6}$

Entre el grupo de mujeres que adoptaron el hábito mercedario se encontraba María de Santa Rosa (1654-1712), una beata singular cuya figura merece una atención destacada por varios motivos. En primer lugar, por tratarse de una beata heterodoxa al eludir su presencia en el beaterio. María sustituyó la forma de beata institucionalizada por la vida eremita en Sierra Elvira, ${ }^{7}$ con la aprobación, y hasta el elogio, del convento masculino. La fugacidad de su presencia en lugares poblados, sus supuestas apariciones y desapariciones misteriosas, los milagros que se le atribuyeron, las visiones que manifestó tener, los dones que se afirmaba le fueron concedidos y, en definitiva, su particular vivencia religiosa, fueron convenientemente difundi-

5 Los predicadores también ejercieron una importante influencia sobre las conciencias de los fieles. Los sermones del maestro san Juan de Ávila pueden mostrar la capacidad de convicción sobre las granadinas. La beata Paz, que era casada, puede ser un buen ejemplo de ello. Otras beatas como Agustina de los Ángeles (OSA) nos muestran la habilidad, entre la convicción y la seducción, para atraer doncellas a la religión. También los confesores obraban en esta dirección, del padre Hernán Núñez se decía que «hace beatas a cuantas doncellas se confiesan con él». Estos solo son algunos ejemplos de los que aparecen en Ruiz de Mesa 1674. A la inversa, también las beatas alcanzaron cierta influencia en los ámbitos religiosos, aunque no siempre con éxito. María de la Concepción, beata rectora de las recogidas granadinas, intercedió ante el arzobispo don Pedro de Castro a favor de la fundación que pretendía la Orden Trinitaria Descalza. Para ello invocó el «muy gran servicio de Dios» que se derivaría de ello, a lo que el arzobispo respondió: «Madre mía, dígale a Nuestro Señor, que pues soy Prelado de su Iglesia, que me lo revele a mí»: Natividad 1697. Según esta anécdota, había beatas capaces de influir sobre los prelados, aunque en esta ocasión no parece que tuviese éxito. Igual se puede decir de la Madre Antonia de Jesús que, siendo beata agustina recoleta, obtuvo favores de prelados y cabildos por su capacidad de convicción.

6 Trabajos relacionados con fundaciones efímeras o fracasadas pueden encontrarse en Atienza López 2012 y 2014, Cortés Peña 2006 y Aranda Doncel 2006. Referido a la orden hermana de los Mercedarios Descalzos, aunque con intención de una fundación de utilidad pública, ver Aranda Doncel 2002. Con la misma intencionalidad: Gallardo Téllez 2000.

La tradición eremítica de la comarca se remonta a tiempos remotos. Por ejemplo, san Rogelio, natural de íllora y martirizado en Córdoba en el año 852, que, según la tradición, vivió como eremita en una cueva de la Sierra de Parapanda, ver Sánchez de Feria y Morales 1782, 21. Más reciente, y seguramente fiable, sea el caso de Bartolomé de la Puerta, cuyo nombre de religión fue fray Francisco de Fiñana, quien, junto a otro joven, vivió como eremita en Sierra Elvira antes de pasar al noviciado capuchino de Sevilla. El caso puede verse en Valencina 1906-1908, 217 y 274. También, en la documentación que hemos utilizado para este trabajo, aparece fugazmente, en la misma montaña, algún eremita contemporáneo a María de Santa Rosa. 
dos, no solo por los frailes mercedarios, sino por una parte significativa del estamento religioso granadino. Todo ello permitió al convento matriz mitificar su figura. La intención evidente era llevar a cabo una fundación mercedaria calzada femenina en Granada, construyendo un modelo de santidad en torno a María. Finalmente, la tentativa quedaría reducida a una tradición localizada en el escenario de su vida eremítica: Sierra Elvira. ${ }^{8}$ Los hechos originales, perdida la memoria de su origen y constituidos en acervo popular festivo, fueron recogidos por el movimiento romántico granadino, material con el que elaboró una leyenda. Por tanto, María de Santa Rosa ofrece al investigador varios ángulos de observación novedosos: beata, eremita y propuesta de modelo de santidad con el fin de llevar a cabo una fundación conventual. ${ }^{9}$

El trabajo que presentamos se estructura en dos bloques claramente diferenciados. El primero de ellos abarca los epígrafes uno, dos y tres. En ellos hemos creído necesario abordar el problema de las fuentes documentales, al estar constituidas por documentación dispersa y compleja en su elaboración original (apartado uno). El epígrafe dos, a modo de sustrato histórico, nos introduce en la presencia mercedaria calzada en Granada. Y el tres, que aborda la presencia femenina en los mercedarios calzados granadinos desde sus orígenes. También se incluyen algunas consideraciones generales sobre el estatus social de las beatas, desprendidas del propio decurso histórico de este beaterio.

El segundo bloque lo constituye el epígrafe cuatro y se encuentra dedicado en su totalidad a la figura de María de Santa Rosa. Se articula en tres apartados: biografía, información de testigos y otras pruebas documentales entorno al proyecto de santidad que se inició en base a su figura. En el tercero analizamos las influencias, modelos y coincidencias de este proyecto con otros personajes y circunstancias históricas. Terminaremos con unas breves conclusiones y las reseñas de fuentes y bibliografía.

\section{LAS FUENTES DOCUMENTALES}

La documentación primaria sobre María de Santa Rosa tiene su origen en el Padre Maestro fray Fernando Del Olmo, del convento de la Merced de Granada. Por testimonio

8 Acosta 1871. Esta tradición se inscribe en el romanticismo tardío granadino. El argumento apenas contiene algo reconocible con su origen aunque, indudablemente, se trata de una adaptación literaria del mismo. Posteriormente sería resumido e incluido en Villarreal 1888, 472-474.

9 Sobre la santidad femenina, sus modelos y evolución, pueden verse Martínez Ruiz 1994, Giordano 2007, Morte Acín 2012 y 2015, Morrás 2015 y Alabrús Iglesias 2016. En 2017 vio la luz el número 43 de la revista Chronica Nova, que incluye un dossier titulado «Santidad y Política: modelos de santos y su vinculación con el poder en la Monarquía Hispana (siglos XV y XVII)». En los artículos que contiene encontramos una óptica distinta de la santidad, esta vez en su relación con el poder. Para el tema que nos ocupa, resultan de especial interés los trabajos de la primera parte, englobados bajo el título «ldea de santidad y procesos de canonización", aunque el volumen al completo es de gran utilidad. Podemos encontrar algunas similitudes con el tema de este trabajo en las colaboraciones de Lozano Navarro 2018 , Martínez Millán 2018, Serrano Martín 2018 y Rivero Rodríguez 2018. Por la misma razón resultan imprescindibles los trabajos de García Bernal 2007 y 2012. Más recientemente, ver Arias Saavedra, Jiménez y López-Guadalupe 2018. propio conocemos que contaba con 81 años de edad en 1768. Por tanto, debió nacer hacia 1687 , es decir, que su vida fue contemporánea a la de María de Santa Rosa durante veinticinco años: entre 1687 y 1712. Habiendo tomado el hábito mercedario muy joven, debió ser testigo durante este tiempo de los hechos de María y de los comentarios que de ella se hacían tanto en la ciudad como en el convento, porque: «afirma que halló muy viva y válida la noticia de una insigne mujer». La muerte de la ermitaña en 1712 no apagó su memoria, continuando esta en forma de procesiones a la Sierra de Elvira y otras devociones. Desconocemos el momento preciso de su larga vida en el que fray Fernando alcanzó el grado de maestro y cronista. Sí sabemos que catorce años después de la muerte de María de Santa Rosa, quizá coincidiendo con el inicio de su responsabilidad como cronista, y a instancia del propio convento, llevó a cabo una información de testigos sobre ella, algo en lo que, según fray Diego Serrano: «... convienen todos los testigos examinados por el P. M. Fernando Del Olmo en el año de 1726».

Según nuestra hipótesis, debió ser a partir de entonces cuando comenzó a elaborar los fragmentos de historia del convento, y personajes allegados a él, que aparecen en los manuscritos incluidos en los fondos de la Biblioteca Nacional. Con independencia de estas pequeñas crónicas, Del Olmo era consciente de la memoria que perduraba de la ermitaña y, estimulado por la información llevada a cabo, decidió asumir el papel de "Tomás», es decir, el incrédulo del caso, e investigar cuánto de verdad había en torno al personaje de la «Santa». Para ello no solo recuperó los recuerdos propios, sino también los dichos y hechos que corrían de boca en boca, acumulando los testimonios verbales, impresos y manuscritos que pudo hallar sobre María de Santa Rosa, algo a lo que destinó gran parte de su vida. Del Olmo, por tanto, es el compilador documental y el origen de la información principal sobre la que descansa este trabajo. Así pues, lo que conocemos de su puño y letra son varios fragmentos que abordan diversos aspectos de la historia de los mercedarios granadinos: unos referidos al propio convento, otros a las beatas mercedarias y otros a la misma María de Santa Rosa. ${ }^{10}$ A su muerte, en torno a 1768 , todos estos papeles o bien se encontraban ya compuestos por él mismo como un único manuscrito, o bien fueron reunidos y ordenados por fray Diego Serrano, quien redactaría el documento completo un año después de la muerte de Del Olmo. Ambas opciones son posibles.

El primer manuscrito está datado en 1769, un año después de la fecha en la que el propio Del Olmo indica que tenía 81 años (intuimos que 1768 puede ser el año de su muerte). Es lo que hemos denominado el «Manuscrito Diego Serrano» que lleva por título: Vida de la Azucena Rosa, Mercedaria, la V. María de Santa Rosa ó por otro nombre la Santa de Sierra Elvira, Beata de la Orden de María Stima. de la Merced, Redención de Cautivos de la Ciudad de Granada escrita por el R. P. M. F. Diego Serrano,

10 Biblioteca Nacional de España, M-BN: Mss. 8293 Colección de escritos tocantes...; Mss. 8730 Papeles varios, manuscritos... y Mss. 3456 Vidas de algunas personas... En su mayor parte se trata de fragmentos copiados de diversos cronistas de la Orden, formando volúmenes facticios. Resulta difícil datar cronológicamente estos fragmentos de historia mercedaria. Nuestra impresión es que en su mayor parte se escribieron a partir de mediados del siglo XVIII. 
Religioso del R. Convento de la misma Orden de dicha ciudad. Año de $1769 .{ }^{11}$ Fray Diego, refiriéndose a Del Olmo, dice textualmente en la introducción: «... se dedicó dicho P. M. ya en los últimos años de su vida a recoger todas las especies que de esta admirable virgen habían quedado y de ellas notó y dejó escrito lo siguiente», dando inicio al relato. Posteriormente (fol. 56), al tratar de los testigos de la información refiere: "Muchos más fueron los testigos examinados por el P. M. Olmo a más de los referidos: pero sus deposiciones desaparecieron por su muerte: y solo estas se reservaron por estar en poder de quien esto escribió». Por tanto, fray Diego reconoce estar copiando una parte manuscrita de Del Olmo y, a la vez, aportando más información que él mismo había conservado. Tratando de averiguar algo de fray Diego, hemos encontrado que, por una parte, existió un fray Diego Serrano (c. 1582-1652), mercedario que llegaría a ser general de la Orden, obispo de Solsona, posteriormente de Segorbe y finalmente de Guadix, en cuya sede pastoral murió. Este mercedario no pudo ser el autor, tanto por cronología como por trayectoria vital. El amanuense, por tanto, debió ser otro fraile mercedario del mismo nombre.

Pero tampoco contamos con la copia «original» de fray Diego, sino con otra que se hizo de ésta en el siglo XIX, esto es, la que don Manuel Gómez-Moreno entregó, acompañada de una carta, en 6 de octubre de 1902, a don Francisco Guillén Robles, responsable de la Biblioteca Universitaria de Granada. Este texto decimonónico contiene numerosas correcciones de tipo hagiográfico y tachaduras que introdujo una persona distinta a quien lo escribió. Se encuentra dividido en 81 fragmentos numerados, de extensión variable, abarcando 126 hojas, y un índice final que los agrupa en tres núcleos temáticos: vida de María de Santa Rosa, testigos examinados y revelaciones. Su estructura, pues, se corresponde con la de una información propia de un proceso de beatificación.

La segunda copia conocida lleva por título Traslado de la Vida de la Ven. María de Sta. Rosa: conocida regularmente por la Santa de Sierra Elvira Hermitaña y Solitaria de ella. Era Beata del Orden de María Stma. de la Merced, Redempcion de Cautivos Cristianos de Granada. ${ }^{12}$ Su autor es Antonio Ramón Almaraso García, de quien carecemos de noticia, y está datada alrededor de 1858. Esta copia consta de 70 hojas, organizando el texto en diez capítulos. Es, por tanto, menos extensa que la precedente. Evidentemente, se trata de un resumen de la anterior, tomando a la letra los episodios y datos más significativos. Almaraso elimina gran parte de la retórica sagrada que acompaña el texto de Serrano, así, su lectura es mucho más fluida, sin percibir el lector sensación de haber obviado ningún dato o hecho importante respecto a la anterior.

11 Se encuentra en la Biblioteca Central de la Universidad de Granada, Hospital Real, bajo la signatura BHR/Caja MS-2-055 (29). También existe copia digital en el repositorio de la misma institución: $<$ http://hdl.handle.net/10481/16698>. El manuscrito va precedido de una carta autógrafa de don Manuel Gómez-Moreno, de la que se extrae la fecha de la donación a la Biblioteca de la Universidad y la persona a la que se le hace entrega. En ella se especifica que el manuscrito es copia de otro anterior que debía conservarse en algún convento granadino.

12 La copia que conocemos se encuentra en la Biblioteca de la Facultad de Filosofía y Letras de Granada.

\section{LOS MERCEDARIOS CALZADOS EN GRANADA}

Conocidas las principales fuentes de información sobre las que hemos trabajado, creemos interesante aportar algunas noticias que aparecen en los fragmentos conocidos del maestro Del Olmo sobre los mercedarios granadinos. La Orden Real y Militar de Nuestra Señora de la Merced y Redención de Cautivos (OM) fue fundada por san Pedro Nolasco en 1218, bajo los auspicios del rey Jaime I de Aragón y la colaboración de san Raimundo de Peñafort, confesor del fundador. A los tres votos habituales de las órdenes religiosas, ésta añadió un cuarto: el rescate de prisioneros cristianos. En ese momento el avance aragonés sobre el este peninsular aún no había comenzado con la intensidad que le impondría posteriormente el rey Jaime, aunque la frontera siempre era un punto caliente. De ello se derivaba la existencia de un gran número de cautivos de ambos bandos. Por tanto, el cuarto voto de la orden naciente abordaba uno de los problemas acuciantes derivados de la situación bélica, a la vez que se inscribía no solo en el contexto de la realidad histórica, sino también en el espíritu evangélico de ejercicio de la caridad y de la recuperación de almas en poder de la religión contraria.

Con este voto como norte mercedario, por razones obvias, apenas transcurrieron unos años desde la fundación para detectar actuaciones de la Orden en Granada, en principio con el fin de proporcionar auxilios espirituales a los cautivos cristianos. Las primeras noticias sobre la llegada mercedaria nos las proporciona fray Fernando Del Olmo. ${ }^{13} \mathrm{El}$ cronista, apoyándose en el historiador Francisco Bermúdez de Pedraza, sitúa su presencia antes de 1230 en el Barrio de los Catalanes, frente a la ubicación de la que sería parroquia de santa Escolástica en época cristiana. Ese mismo año tuvo lugar la primera redención de cautivos, a cargo de fray Guillermo Bas, y dos años más tarde se llevó a cabo la siguiente por mediación de fray Berengario Casano y fray Domingo Doso, uno de los cuales, siguiendo la crónica del maestro mercedario, se quedó en la ciudad. Ésta permanencia iniciaría la presencia mercedaria continuada, ejerciendo de cura en la iglesia de san Cecilio, donde se ubicó un centro de atención a los cristianos granadinos. Las redenciones sucesivas, en las que participó el mismo san Pedro Nolasco, no estuvieron exentas de violencia, recibiendo martirio en tierras granadinas fray Raimundo de Blanes (1235) y fray Jaime de Soto (1237).

Con estos precedentes, entre el discurso de los orígenes y la hagiografía, la toma de la ciudad en 1492 nos sitúa en terrenos documentalmente más sólidos. ${ }^{14}$ Ese año era provincial de Castilla fray Jorge de Sevilla, predicador y consejero de los Reyes Católicos, a quienes acompañó en la jornada final del Reino Nazarí. Esta posición privilegiada permitió la instalación mercedaria en Granada el mismo año de la toma de la ciudad. La primera ubicación conventual estuvo situada en lo que posteriormente sería el hospital de san Lázaro, extramuros de la misma. El cambio de emplazamiento del solar primigenio, donde ya estaba construida la iglesia, ${ }^{15}$ se

13 Olmo (OM)a, M-BN, Mss. 8293, fragmento 2: 1-22. Se trata de un volumen facticio del que iremos dando cuenta de los fragmentos de interés para este trabajo.

14 Olmo (OM)b, ibídem, fragmento 3: 25-27.

15 Según Olmo fue la primera que se terminó en Granada tras la toma de la ciudad y la primera donde se dijo misa el mismo año de 1492. 
produjo en el año 1500 por el deseo de los reyes de construir un hospital para los leprosos retirado de la urbe. Esta segunda fundación, llevada a cabo por fray Antonio de Valladolid y fray Raimundo de Foch, también se situó fuera del recinto amurallado, en el llano del Campo del Triunfo, el lugar donde, según la tradición, había recibido martirio el protomártir de la Orden san Raimundo de Blanes.

Las obras del nuevo convento comenzaron pronto, aunque se alargarían en el tiempo hasta bien entrado el siglo XVIII. Fueron benefactores del mismo Luis Fernández de Córdoba y su esposa Elvira Fernández de Córdoba, hija del Gran Capitán. No obstante, ante la falta de recursos para continuarlas, fueron necesarias varias bulas de los papas León $X$, Adriano VI y Clemente VII concediendo jubileos. León X, con el favor de Carlos V, concedió dos años de jubileo pleno a quienes visitasen la antigua iglesia el día de la Asunción y entregasen la limosna que fijase el comendador; también se podía visitar cualquier otra iglesia de España y hacer llegar a Granada la limosna que se pudiese. Con ello la iglesia alcanzó los catorce pies. En los mismos términos concedió otra bula Adriano VI, a petición de los Fernández de Córdoba, para el día de la Concepción de 1523 y para la Natividad de 1524. Con ello los muros conventuales alcanzaron su altura total. Estas concesiones se vieron prorrogadas por Clemente VII en 1526 y 1527 , con lo que se consiguió terminar la iglesia, en la que figuraban las armas de Alonso de Zurita, comendador de entonces. La capilla mayor fue financiada por el patronato de don Juan Muñoz de Salazar, quien obtuvo derecho de enterramiento para él y sus descendientes, confirmado por bula de Paulo V en 1558. La finalización de las obras y el ornato de la iglesia fueron costeados por diversos comendadores del convento y otros religiosos de la Orden. ${ }^{16}$

\section{LAS «HERMANAS» MERCEDARIAS GRANADINAS: BEATAS Y BEATERIO}

Es evidente que las hermanas mercedarias existieron casi desde los inicios de la Orden, recibidas por el propio san Pedro Nolasco. ${ }^{17}$ Con este breve comentario se da cuenta del inicio de la presencia femenina en la historia de la Orden de la Merced. En principio se trató de mujeres, agrupadas en comunidad, que profesaban el hábito mercedario. El propósito de la Orden era la formación de beaterios, aunque no todas las mujeres allegadas a los mismos se integraron en estos cenobios, ni todas las candidatas a vestir el hábito

16 En 1598 había profesado don Diego Serrano, que no debemos confundir con su homónimo autor del manuscrito. Ya hemos apuntado que fue provincial, general de la Orden, obispo de Solsona, de Segorbe y de Guadix-Baza. Bajo su prelacía se labró la escalera principal, se renovó el coro alto y enriqueció el convento con ornamentos. Murió en 1652 , fue enterrado en el convento, en una capilla elaborada para este fin. El atrio y la portada se comenzaron en 1648 y terminaron en 1654. El púlpito se colocó en 1662. En 1690 se enlució la iglesia (costeado por fray Juan de Venegas) y se retiró el retablo viejo del altar mayor. El nuevo se comenzó en 1713 con la contribución de fray Juan Lisón, que también costeó el retablo del altar de santa María del Socorro. El frontal de piedra del altar mayor se hizo en 1722, por caridad de fray Feliciano Palomares, que también pagó la sillería del coro. Los claustros bajos estaban adornados con lienzos sobre la vida de san Pedro Nolasco y otro pequeño de los apóstoles. La imagen del coro de Nuestra Señora de la Merced corrió a cargo del comendador fray Melchor Martín, que también pagó el aljibe de gran capacidad construido en 1726.

17 Instituto Histórico de la Orden de la Merced 1997, 34. fueron aceptadas. Sin ánimo de mezclar mercedarios calzados y descalzos, cuya política de admisión posiblemente fuese distinta, conocemos las negativas que padeció Juana de Cristo (1586-1616) en Fuentes de Andalucía ${ }^{18}$ antes de recibir el hábito mercedario descalzo. Las sucesivas negativas del Provincial de la Orden a la profesión de Juana, y en general a las profesiones de beatas, detuvieron sus deseos durante un tiempo. Posteriormente profesaría ante el prior del convento masculino, aunque ocultándoselo al provincial por temor a un nuevo rechazo. Finalmente sería recibida en la Orden, en la que permanecería hasta su muerte en olor de santidad. No es el único caso que conocemos de discrecionalidad en la admisión a los beaterios, bien por la jerarquía de la Orden a la que se encontraban sujetos, bien por la religiosa que ejercía como "priora» del cenobio. ${ }^{19}$

Volviendo a los beaterios mercedarios existentes al tiempo del Concilio de Trento, éstos se transformaron en monasterios de clausura, siguiendo las directrices emanadas del mismo. En 1603 se inició la andadura de la rama mercedaria descalza, que también tendría su prolongación femenina con sus propios beaterios y conventos. Llama la atención la distribución geográfica de unos y otros. Mientras los conventos de monjas calzadas establecieron sus fundaciones en el centro y norte peninsular, los descalzos mostraron una pujanza sorprendente en Andalucía Occidental: Lora del Río (1617), Fuentes de Andalucía (1620), Osuna (1626), San José de Sevilla (1633) y Marchena (1637). A la par que se fundaban conventos, continuaron existiendo los beaterios, y las beatas, de adscripción mercedaria. Los crecidos recursos necesarios para llevar a cabo una fundación ejercieron de filtro eficaz para su implantación o continuidad.

Las primeras noticias fehacientes sobre profesiones de mujeres en el convento mercedario de Granada se remontan a $1591^{20}$ (Catalina Rodríguez y Quiteria Rodríguez de los Santos), a las que le seguirían Ana de la Cueva, que profesó en 1597, y María de la Paz que lo hizo el 14 de octubre de 1609. Del Olmo y las demás crónicas consultadas no ofrecen más detalles sobre ellas, aparte de los encomios propios de un relato hagiográfico. Muy posiblemente, durante los cien años anteriores de presencia de la Orden en Granada hubiese otras mujeres que, aun no llegando a profesar, llevarían una vida religiosa próxima al convento masculino.

El hilo conductor femenino surgido al amparo de los mercedarios calzados granadinos se ve documentalmente interrumpido hasta 1660, aproximadamente. Cincuenta años de silencio. Previamente, aunque desconozcamos la fecha concreta (debió ser en los años en torno a la mitad del siglo, muy próximo al nacimiento de María en 1654), sabemos que un grupo de mujeres había formado una congregación independiente en una casita destartalada en el camino del Sacromonte. ${ }^{21}$ La escasa renta que pagaban, la «libertad que lograban»

18 Ver González Fernández 2016.

19 La madre Antonia de Jesús, agustina recoleta, relata en sus escritos los criterios de selección de las candidatas, que se pueden resumir en cuatro palabras: vocacionales, bellas, nobles y pobres. El objetivo tenía lógica en su momento histórico y en la mentalidad religiosa de la época, porque se trataba de proporcionar una "salida» a un segmento social en riesgo de pecado. El resto de aspirantes se dirigían a otros beaterios o a practicar una religiosidad personal en su propia casa.

20 Olmo (OM)c, fragmento 11: 86-90.

21 Ibídem, fragmento 35: 366-375 v. 
en el ejercicio de su espiritualidad y la proximidad de la reverenciada abadía sacromontana, donde eran atendidas por el canónigo don José Barcia, convertía el lugar en ideal para su modo de vida. En la comunidad ejercía como «priora» María de la Concepción, de apellido Bocanegra en el siglo, según declararon algunos testigos de la información llevada a cabo por Del Olmo. De las demás componentes del grupo solo sabemos que eran Jacinta Ramos y Juliana Calzado, si había más beatas en ese momento, desconocemos sus nombres.

En este punto, cuando el beaterio aún no había entrado en la esfera de influencia mercedaria, creemos de interés traer a colocación el testimonio de los sucesos que acaecieron, porque nos acercan, de forma sobrecogedora, a la consideración social de la beata en aquel tiempo. María de Santa Rosa no debió presenciarlos, tanto por su corta edad (por entonces contaría con tres o cuatro años), como por la lejanía de su parroquia, san Ildefonso, del camino del Sacromonte. Fue su prima, María de la Concepción y las demás beatas ya mencionadas, quienes los sufrieron. Entresacamos algunas frases significativas.

\begin{abstract}
...recibieron insultos, palabras obscenas y provocativas [...]; las amenazaban con la ronda y la justicia y que viéndolos y hallándolos a ellos allí las llevarían a las recogidas [...]; llegaban otros a la puerta en forma de ronda y justicia [...]; y todo paraba en darles muchos golpes y llenarlas de afrentas y oprobios [...] amenazando con llevarlas al tribunal de la Santa Fe [...]; sustanciándole allí a nuestra María su proceso por hipócrita, embustera y otros mil delitos que la acumulaban, la sentenciaron a azotes y coraza, que todo se ejecutó allí efectivamente y desnudándola y poniéndola en un jumento la pusieron una irrisible coraza y la dieron muchísimos azotes a la vista de las demás hermanas [...]; quererlas ahogar, quitarles la ropa, y los silicios, y desnudarlas en carnes y darles cruelísimos azotes era lo más cotidiano. ${ }^{22}$
\end{abstract}

Poco hay que añadir a un testimonio tan explícito. Hasta se llegó a simular un proceso inquisitorial espontáneo, cuya pena se ejecutó en el mismo momento. Por tanto, la opinión pública, al menos una parte considerable de ella, estimaba que no se trataba de religiosas propiamente dichas, a lo que se sumaba una reputación imprecisa, socialmente entendida desde ópticas contrarias. Estas consideraciones oscilaban en un umbral tan amplio que abarcaba desde su estimación, por unos, como mujeres respetables en su opción vital, hasta personas marginales, objeto de iras y escarnio público, por otros. Esta afirmación puede que no sea generalizable a todas las beatas y beaterios, pero sí es cierto que la versión más negativa también se dio en casos distintos al que tratamos. Por ejemplo, las beatas sujetas al convento de agustinos recoletos del Albaicín, sufrieron humillaciones y actitudes agresivas por parte de la multitud en 1667. Luego, no se trató de un caso aislado.

Hecho este breve inciso, continuamos con la evolución del beaterio. Las circunstancias eran tan adversas en el camino del Sacromonte, que el grupo decidió mudarse a otra parte de la ciudad. El traslado de esta primera ubicación se encuentra envuelto en una narración de tintes celestes. La casa debía ser de tan humilde factura que terminó por derrumbarse la techumbre, sin alcanzar a ninguna de ellas (hecho justificado con el necesario prodigio propio de estos

\footnotetext{
22 Ibíd. 366 y ss.
}

casos). La mudanza a la calle Coca, en la parroquia de san Andrés, no impidió que continuaran las persecuciones, humillaciones y desafueros que venían padeciendo en la ubicación anterior. Ahora bien, la proximidad de su nueva casa con los mercedarios calzados permitió la asistencia a misa y la toma de confesor en el convento. De ahí a adoptar el hábito de la Orden solo había un paso que, en el caso de María de la Concepción, se produjo en noviembre de 1666, profesando tras un año de noviciado. A ella le seguirían Juliana de Jesús en 1670 y Jacinta de santa María en 1674. Ésta moriría cuatro años después y sus compañeras al año siguiente, víctimas de la epidemia de peste que asoló Granada en 1679.

Por este tiempo, el beaterio ya se había trasladado a la Calle Real, donde comenzaba el camino hacia el convento franciscano de San Antonio. ${ }^{23}$ La parroquia de San Andrés es contigua a la de San Ildefonso y la calle Real podríamos decir que es el centro de esta última. Aquí es donde aparece nuestra protagonista como visitante del beaterio que dirige su tía. Por tanto, el contacto de María de Santa Rosa con las beatas mercedarias debió tener lugar a comienzos de la década de 1660 , cuando contaba con unos seis años de edad. Una relación que se prolongaría durante los años siguientes, residiendo por temporadas en el mismo beaterio. Según el relato de Del Olmo, cuando lo visitaba, dormía en una pequeña cueva que existía en el oratorio del mismo, entendemos que a modo de premonición de su propio futuro.

Estas mudanzas obedecen a un proceso de ajuste vital del grupo en particular $y$, en general, a un mecanismo de defensa de las mujeres que habían optado por integrarse en el segmento social religioso y que, por una u otra razón, no alcanzaban el estado de monja. Situarse bajo la protección de un convento masculino, vestir su hábito y seguir sus pautas, suponía para ellas una garantía de paz, de tolerancia y hasta de «integración» social. Aquellas primeras beatas mercedarias granadinas que conocemos, que profesaron en la década final del siglo XVI y primera del XVII, quizá también fueron empujadas a ello por el rechazo social. Aunque esto sea mera hipótesis en su caso, lo cierto es que recibieron otro tipo de presión, esta vez de tipo institucional. Las dos décadas en las que se efectuaron sus profesiones coinciden con la prelacía en la archidiócesis granadina de don Pedro Vaca de Castro y Quiñones (1589-1610), un arzobispo que prohibió los hábitos no reconocidos por la Iglesia (que pululaban por doquier) y que, siguiendo los principios tridentinos, intentó la institucionalización de todo individuo que pretendiera situarse bajo el paraguas de la Iglesia.

Así pues, de las crónicas citadas se desprende que, con certeza, hubo beatas mercedarias profesas en Granada desde finales del siglo XVI. Por otra parte, un núcleo independiente de al menos tres terminó profesando y formando beaterio en las dos décadas siguientes a la segunda mitad del siglo XVII. Entre ellas se encontraba María de la Concepción, tía de María de Santa Rosa, que, como hemos dicho, ejerció de "priora» del grupo desde los orígenes hasta su muerte. Con estos mimbres podemos preguntarnos: ¿había propósito fundacional femenino en la Orden de la Merced Calzada granadina?

23 Las noticas sobre estas beatas pueden encontrarse en Olmo (OM)d y f, fragmentos 32: 342-345 v. y 33: 346-353; Esteban fragmento 35: 366-375. 
El contexto fundacional, a nuestro juicio, tiene dos vertientes que valorar. Por un lado, las fundaciones descalzas femeninas de la Orden Mercedaria, detenidas desde la llevada a cabo en Marchena en 1637, que habían progresado más que las de la rama calzada, lo cual debía pesar en su ánimo. Por otro, existía un evidente desequilibro geográfico, ya que no se habían instalado conventos femeninos de ninguna de las dos ramas en la Alta Andalucía. No resulta extraño, por tanto, que en el seno de los mercedarios calzados granadinos anidara el deseo de una fundación femenina encabezada por María de la Concepción. En las crónicas que hemos manejado su figura se adorna de virtudes, tribulaciones, ejercicios, devoción, etc., es decir, todas las cualidades necesarias para encabezar este proyecto.

El otro factor que debemos tener en cuenta es el contexto local. Las fundaciones conventuales femeninas en Granada, partiendo de beaterios preexistentes, habían tenido importancia durante el siglo XVI, retomándose en 1655 con la llevada a cabo por las agustinas recoletas de Corpus Christi. Entre la profesión de María de la Concepción en 1666 y la de Juliana de Jesús en 1670, se había producido la primera fundación, frustrada, del Convento de agustinas recoletas de Santo Tomás de Villanueva. Flotaba, pues, en el ambiente religioso granadino de ese tiempo la posibilidad de llevar a cabo fundaciones, aunque posiblemente la escasez de efectivos en el beaterio mercedario, y de patronazgo, lo impidiera por el momento (solo tenemos conocimiento de tres beatas, mientras las dos fundaciones recoletas agustinas alcanzaban e incluso superaban la veintena de novicias). La muerte de María de la Concepción obligó a modificar el proyecto fundacional. Había que encontrar otro camino.

4. Un PROYeCto de SANTIDAd. la beata María de SANTA ROSA, MÁs CONOCIDA COMO LA SANTA DE SiERRA ELVIRA

\subsection{Sobre la biografía de María de Santa Rosa.}

Las noticias que poseemos de María de Santa Rosa son relativamente abundantes, aunque fragmentarias y envueltas en una retórica hagiográfica que deja muchos puntos de su vida en la sombra. ${ }^{24}$ Como comentábamos más arriba, la estructura del "Manuscrito Diego Serrano» sigue las pautas de la información que se llevaba a cabo para iniciar un proceso de beatificación: datos vitales, averiguación de testigos, documentos testimoniales, etc. A ello debemos acogernos para aproximarnos a la vida de la ermitaña. Los datos biográficos con que contamos son los siguientes.

María de la Rosa Liñán, en el siglo, nació en Granada en 1654, hija de Juan de la Rosa, natural de Andújar, y de María Liñán, nacida en Béznar, en el Valle de Lecrín. Fue bautizada en la parroquia de san Ildefonso el 20 de enero de ese año, ${ }^{25}$ quedando huérfana a la edad de diez o doce años. Esta circunstancia permitió, incluso pensamos que de alguna forma pudo obligar, que las anteriores estancias más o menos prolongadas de la niña en el beaterio se transformaran en

24 Además de los manuscritos de la Universidad de Granada que referimos más arriba, puede verse Olmo (OM)e y g, fragmento 34: 354 365 y 37: 384-391. También Esteban 35, 366-375.

25 El compadre fue Jerónimo López y los testigos Sebastián de Escribano y Lorenzo Cortés. El cura Francisco Montesino. Archivo de la Iglesia Parroquial de san Ildefonso, Libro de Bautismos 10, fol. 219. residencia permanente. Haciendo un cómputo aproximado, este hecho debió producirse en torno a la profesión de su tía María de la Concepción en 1666. Continuó residiendo en el beaterio hasta que se celebraron en Granada las fiestas de beatificación de santa Rosa de Lima, ${ }^{26}$ primera mujer criolla elevada a los altares. Impactada por este hecho y los eventos de que fue testigo en Granada, decidió emular a la beata de la Orden de Santo Domingo, adoptando el eremitismo como forma de apartamiento del mundo. Estos acontecimientos tenían lugar en 1668, contaba pues con catorce años de edad.

Hasta aquí los datos más o menos objetivos que conocemos de María de Santa Rosa porque, a partir de entonces, todo lo que sabemos de su vida se encuentra envuelto en las sombras que proyecta un relato hagiográfico inmerso en la más pura tradición de la oratoria sagrada, a pesar del formato de averiguación que presenta el manuscrito elaborado en origen por fray Fernando Del Olmo. Según este, los deseos de soledad, apartamiento e imitación de la beata limeña se vieron satisfechos con la aparición de un ángel que la transportó a una cueva de Sierra Elvira, término de Atarfe, pago de la Cuna: "Alma ya llegó el tiempo en que quita el Altísimo dar cumplimiento a tus deseos; y tomándola de la mano, y sin más prevención que una manta o paño de cama, la trasladó de un vuelo a la cueva». Esta cueva no sería la definitiva de su morada porque, en octubre de 1671, una nueva traslación celestial la llevaría a otra, dentro de la misma sierra, en término de Albolote, donde vivió hasta su muerte el día nueve de marzo de 1712, a los 58 años de edad.

De estas fechas concretas, que parecen firmes por su precisión, debemos decir que, excepto el bautismo, las demás se encuentran desdibujadas en la nebulosa de los indicios y edulcoradas por una retórica que acude deliberadamente a lo sobrenatural. La evidente intención del cronista es envolver los hechos en un halo de imprecisión, de misterio, solo explicable por intervención sobrenatural y, en consecuencia, divinamente mediatizados. Entre sus fines destaca dejar fuera de cualquier duda que la ermitaña es una persona elegida para la santidad. Unos ejemplos nos ayudarán a un mejor entendimiento.

Su muerte, que se dio por cierto que había sucedido la noche del nueve de marzo de 1712, fue deducida del testimonio del cura de Albolote que, sobresaltado en la noche, despertó al oír la campanilla que anunciaba la salida de la iglesia del viático, camino de administrar los últimos sacramentos a un enfermo. Al día siguiente nadie reconoció haber participado en dicha salida: ni sacristán ni teniente de cura. Además, únicamente con el testimonio de un niño, con solo días de vida, que milagrosamente habló anunciando claramente la muerte, se tomó como cosa cierta. La misma mañana, el acontecimiento fue vox populi en Granada y

26 La beatificación de santa Rosa de Lima supuso un hito para la Iglesia Católica, por las connotaciones novedosas que aportaba: mujer, criolla, beata, eremita etc., y como tal fue celebrado en todo el mundo católico, aunque su canonización no llegara hasta 1671. Granada no fue ajena a los festejos: sermones, certámenes poéticos, dramatizaciones, manifestaciones de fervor, actos litúrgicos, fiestas, etc. se sucedieron, sin faltar memoria de estos acontecimientos, ver: Relación breve... 1668. Ese mismo año se publicaron en Granada obras sobre el acontecimiento, por ejemplo, Albornoz 1668. En la bibliografía moderna ver Montes González 2010. 
sus contornos. Nadie vio el cadáver, aunque se publicó la posición santa en que quedó en su cueva, a la espera de su descubrimiento en un hipotético futuro.

Igual ocurre con su toma de hábito, otro hito importante envuelto en circunstancias sobrenaturales, porque el uso del "santo hábito» mercedario y su supremacía sobre las demás religiones, es una constante a lo largo de la crónica. Una reivindicación, por otra parte, común al resto de órdenes, aunque, en este caso se deja entrever una conflictividad entre conventos, más insinuada que explícita, que, a decir del cronista, no se hubiese producido de seguir los consejos mercedarios. Según una carta que la ermitaña envió a su prima María de la Concepción, reproducida en ambos manuscritos, recibió la profesión en 1673, cinco años después de ser transportada a la cueva, cuando contaba diecinueve años de edad. A nuestro juicio, el autor de la carta es el mismo que el de la crónica, por las similitudes de estilo y vocabulario. Según el relato de Del Olmo, María, anticipándose a su venida al convento para la investidura, recibió en su cueva la visita de santa María del Socorro (recordemos que en el convento había un altar dedicado a esta advocación) y de santa Rosa de Lima (su modelo de santidad) que, por gracia y favor sobrenatural, llevaron a cabo la ceremonia. Fueron los portadores del hábito san Pedro Nolasco y el cardenal Nonato:

Habiendo pues recibido la V. María este favor del Cielo, y vestido el santo Hábito Mercedario, y pasado el coloquio, que por más de tres horas tuvo con dichos santos y santas, se puso a dar gracias al Señor; el que se la manifestó Crucificado y la dijo: Alma, de aquella infinita caridad, con que yo redimí al mundo, dando la vida afrentosamente en la Cruz, es el espíritu y vocación que yo puse en esta Religión .... ${ }^{27}$

La cita evidencia lo milagroso del acto, el favor divino de que goza María y la pretendida superioridad mercedaria sobre las demás órdenes. Consecuentemente, entre las profesiones documentalmente probadas de las beatas mercedarias no aparece la suya. En este tono se desarrolla el discurso del manuscrito. Por ello es posible afirmar que la existencia de María fue real, aunque el propio misterio en el que de forma deliberada se relata su vida, impide establecer unos hechos y una secuencia concreta en su desarrollo. A la vez, estas mismas circunstancias, posibilitaron que el convento de mercedarios calzados intentara establecer un proyecto de santidad basado en su figura. El fin último declarado, con el intento de beatificación como medio, era llevar a cabo una fundación mercedaria femenina. Un propósito no oculto en aquellos momentos, aunque diferido en el tiempo: «... y este suceso (el descubrimiento del cuerpo incorrupto de María de Santa Rosa) dará motivo para que se funde en Granada un convento de religiosas de la Merced muy observantes y recoletas». ${ }^{28}$ Por tanto, la prioridad del autor no es detenerse más de lo necesario en la vida de María en el siglo, sino destacar el contexto espiritual en el que se vio envuelta. Por otra parte, las declaraciones de los testigos tampoco ayudan a esclarecer los hechos, como veremos a continuación.

\footnotetext{
27 Serrano 1769, 19 r.

28 Serrano 1769, 38.
}

\subsection{La Información de testigos y las pruebas documentales}

Una parte importante del documento está destinada a la información de los testigos, tanto seglares como religiosos, llevada a cabo «por el P. M. Fernando Del Olmo en el año 1726» según reza en la crónica, es decir, casi quince años después de la muerte de María. La iniciativa perseguiría el objetivo de sustanciar de alguna forma el recuerdo de la ermitaña, todavía vivo entre la población, siguiendo un esquema semejante al "oficial». Para ello era necesario recoger las declaraciones de personas que la hubiesen conocido o tuviesen referencias cercanas. Todo ello con el fin de iniciar un futuro proceso de beatificación. Ahora bien, transcurridos tantos años, muchas declaraciones se habían perdido, conservándose solo aquellas que se encontraban en poder de fray Diego Serrano, como ya dijimos anteriormente. A continuación ofrecemos un sucinto resumen de las mismas.

Entre los testigos seglares se encuentran: María de Medina, vecina de Albolote, de más de setenta años, que la conoció y trató. Entre otros milagros, testifica el hecho de que se arrodillara en el vientre de su madre al paso del Santísimo en el Campo del Triunfo. Que con tan solo tres años se arrodillase al paso de fraile mercedario que portaba el Santísimo, quien pronosticó a su madre que "sería muy agradable a Dios». Y que, siendo niña y estando retirada en su casa, se le apareciera la Virgen avisándole de un incendio que se había iniciado en el lino almacenado, incendio que sofocó con sus enaguas.

Otros informadores fueron Alonso de Prados y Juan Jerónimo Jiménez, que proporcionaron una descripción física de María. Luis Verdejo, Lucas de Rege y Fernando Arantave Verdejo, todos de avanzada edad, informaron de la existencia anterior de otro eremita llamado Juan Giménez, y de los prodigios que vivió un tratante de vinos de Granada cuando visitó la cueva, después de haber tenido un sueño reiterado. En su interior pudo ver cadáveres sangrantes y otros horrores. El comerciante murió en paz tres días más tarde. D. Francisco Bermejo, médico, testimonió haber oído decir que era muy favorecida de Dios, de su milagrosa traslación a la cueva e investidura de hábito. También contó, entre otros hechos sobrenaturales, lo que ocurriría cuando se descubriera el cadáver de la comúnmente denominada santa de Sierra Elvira, esto es, que a lomos de una bestia iría en olor de multitud hasta el convento mercedario de Granada. Juan Muñoz y su hermana aportaron que su apellido era Bocanegra y que se crio en la parroquia de San Miguel (quizá exista aquí una confusión con su prima María de la Concepción). María Valenzuela, de sesenta años y ama don Juan Fernández, beneficiado de Pinos, declaró haber oído decir al canónigo Baltasar de Rienda, y a otros muchos vecinos, que la habían visto en la sierra y en la iglesia vestida de blanco. En general, el traslado milagroso a la Sierra de Elvira es algo en lo que «convienen todos los testigos examinados por el P. M. Fernando Del Olmo en el año 1726». La presencia del diablo también es una constante en los testimonios: «no se descuidaba su infernal astucia en armarla todos los lazos, mentiras y enredos que podía su depravada malicia, impedirla, atribularla y afligirla. Así lo dicen todos los testigos de sus informaciones».

Los declarantes eclesiásticos fueron, entre otros, Salvador de Anguita, sacerdote del convento de la Victoria y beneficiado de Atarfe, que fue su confesor durante varios 
años. Pedro Antonio Pérez Mazuecos, licenciado, cura de íllora y comisario del Santo Oficio. Félix de Lara, cura de Atarfe. Fray Cipriano Fernández Donado, del convento de san Antonio de Padua. José de Hita, que también fuera beneficiado de Atarfe, y Pedro Mazuecos, cura del mismo pueblo, que la confesó en alguna ocasión. Todos ellos coinciden en varios puntos: en la ubicación de la cueva donde vivió «junto al Peñón Bermejo, término de Atarfe». En su descripción física: «una mujer de buena estatura, ni muy alta, ni muy baja, cari agucena (sic), delgada y de pocas carnes, blanco el color del rostro y las manos, aunque lo más elevado de la cara tenía el color algo tostado». Por otra parte, insisten en la fugacidad de sus apariciones en iglesias y conventos, en lo difícil de verle el rostro y en sus misteriosas desapariciones tras los oficios religiosos. Quienes fueron sus confesores testificaron que fue un alma pura.

El otro componente importante del documento comprende las obras, manuscritas o impresas, que de algún modo contienen noticias de la santa de Sierra Elvira. Entre ellos se citan dos manuscritos. No hemos podido localizar el de Catalina Ledesma (Catalina de san Miguel) que posiblemente haya desaparecido por los avatares de la historia, o se encuentre en los anaqueles de algún convento. Esta religiosa del monasterio de Santa Isabel de Granada, al parecer, mantuvo una comunicación privilegiada con María, ya que estuvo un tiempo con ella en la cueva antes de profesar y deseó ser su compañera de soledad, siendo disuadida de ello por la eremita. En la referencia a los escritos de Catalina (alarde de exaltación de la beata y de la Orden Mercedaria) se relataban milagros, curaciones, trabajos, disciplinas, penitencias, devociones, muerte y otras circunstancias que acompañaron a María en su retiro. También relata la Vía Sacra y misas que celebraba acompañada de ángeles y santos, ${ }^{29}$ motivo de las luces que se veían en Sierra Elvira desde toda la comarca. Muy posiblemente este sea el origen de la posterior tradición que se continuaría hasta el siglo XX:

Estando esta sierva de Dios [Catalina de san Miguel] en la iglesia en el día de S. Pedro Nolasco asistiendo a su fiesta, se le apareció el dicho y la dio a entender la fiesta que se hacía en la sierra este día, como se había hecho otras veces después de la muerte de la V. Hermitaña (...) porque su cuerpo la ayudó a ganar, y fue caja y concha de tal diamante y tesoro, es voluntad del Altísimo, que éste goce algunos días de la gloria, que posee su Alma y por eso se baja a donde está su cadáver. ${ }^{30}$

Otros pasajes vienen a confirmar lo que decimos: «Diferentes veces manifestó la Divina Majestad a su siervo fr. Francisco multitud de luces, que en forma de ordenadas procesiones discurrían por la Sierra de Elvira, monte cercano a la ciudad de Granada». ${ }^{31}$

El otro manuscrito es conocido, se trata de la historia mercedaria que escribió fray Fernando Colombo, ${ }^{32}$ en el que, el autor introdujo una nota marginal dando fe de una reliquia «purísima» del hábito de María.

29 Incluye algunas canciones de María, como la que sigue: El temor santo es amor /el amor es padecer / el temor es confianza / la confianza es temer /el temor solo es error / confiar solo osadía / uno sin otro flaqueza /ambos juntos valentía.

30 Serrano 1769, $114 \mathrm{r}$.

31 Ibídem $97 \mathrm{r}$.

32 Colombo M-BN, Mss. 4159.
En cuanto a obras impresas se cita el sermón de fray Pedro Rosiqué sobre la vida de fray Francisco Molinero del convento de san Antonio de Padua. ${ }^{33}$ Este fraile, que fue confesor de María durante casi toda su vida, también fue biografiado ${ }^{34}$ por uno de los religiosos más famosos de la época: el padre Tomás de Montalvo. ${ }^{35}$ En ambos se encuentran testimonios de los favores divinos que disfrutó la beata y de las luces de procesión que se veían por Sierra Elvira en días religiosamente relevantes. La obra de fray José de san Lorenzo sobre la religiosa Tomasa del Espíritu Santo ${ }^{36}$ presta el testimonio de Antonio Rodríguez, que visitaba a la santa en su cueva. Ésta le confió que había asistido a la muerte de Tomasa en compañía de otras religiosas, las cuales se encontraban en paradero muy distante a Granada en el momento de la defunción. Este testigo aparece en diversas ocasiones a lo largo de crónica, siendo una de las pocas personas cuya compañía toleraba la eremita.

Pero la que quizá sea la obra más destacada por Del Olmo, aparte de los escritos de Catalina de san Miguel, es el «Tesoro espiritual ॥" del canónigo sacromontano Baltasar de Rienda. Según Del Olmo, Rienda no cita a la santa eremita por su nombre porque todavía estaba viva. Lo cierto es que nosotros no hemos encontrado indicio alguno de la relación Tesoro Espiritual / Santa de Sierra Elvira. A pesar de ello, Rienda fue el primer confesor, director espiritual y propagandista del prodigio María de Santa Rosa, incluso, puede que su «constructor». El argumentario teológico que Del Olmo extiende sobre ella, partiendo de la obra de Rienda, configura una visión panorámica inserta en la más pura religiosidad barroca: visiones, manifestaciones celestiales, raptos espirituales, visitas celestiales e infernales, etc. Apoya esta hipótesis la enumeración que hace de las faltas comunes, y penas más tenebrosas, que afectaban tanto al estamento religioso (monjas, prelados, sacerdotes, confesores, predicadores, etc.) como al seglar (ancianos, doncellas, mancebos, etc.). De hecho, con los velados testimonios de Rienda sobre la ermitaña comenzó lo que podríamos llamar la «popularidad» de María, su «protosantidad» y el «jubileo» popular a Sierra Elvira.

En relación con lo que decimos, en otros pasajes, Del Olmo, profundiza en los males que aquejan la ortodoxia religiosa. Así, en las visiones que María tiene del purgatorio y del infierno, encontramos su denuncia explícita: monjas que no observaban su profesión por aplicarse al «trato con las criaturas", prelados laxos en las confesiones, confesores que no corregían, sacerdotes de mala vida, predicadores de "flores para el oído», etc. En el ámbito seglar no es menor el recuento: madres que pecaron por dar gusto a las hijas; casadas viciosas, "muy profanas», amantes de las galas; doncellas desmañadas que se deleitaron con su «cuerpo y hermosura», aquellas que con sus "aliños» y trajes profanos

33 Rosiqué 1695.

34 Montalvo 1698.

35 El padre Montalvo escribió varias obras entre la que destaca su Práctica política y económica de expósitos (Granada, 1701), que contó con varias ediciones.

36 Lorenzo [ca. 1709].

37 Rienda c 1680. Existe otra edición de 1683, fecha que el cronista de la santa de Sierra Elvira confunde con 1693. Rienda fue un canónigo sacromontano de amplio prestigio, al menos local, con fama de buen confesor y director de almas, ver: Rienda 1662a y $1662 b$, obras propuestas en algún caso como ejemplo de predicación rural. 
hicieron pecar a otros, etc. Lo cierto es que la mayor carga de la crítica recae sobre las mujeres, que son quienes encarnan la fuente del pecado, como es lógico dentro de una visión androcéntrica del mundo.

\subsection{Influencias, modelos y coincidencias}

Hasta aquí unos someros apuntes sobre el contenido del manuscrito, un documento que requeriría un análisis propio de la retórica sagrada. A lo largo de su lectura hemos detectado una serie de influencias, implícitas y explícitas, que creemos interesante anotar. Por ejemplo, el Libro de las Fundaciones de santa Teresa de Jesús que, en el capítulo 28, anota el caso de la beata Catalina de Cardona, del eremitorio de N. Sr. del Socorro (una vez más, aparece una de las advocaciones que impuso el hábito mercedario a María). La similitud, que concede un marchamo de autoridad, se establece porque Catalina trabajó para conseguir una fundación carmelita descalza ligada a la santa abulense, sin renunciar a su condición de beata. Igual ocurre con santa Rosa de Lima, otra beata, también elevada a los altares y elegida como modelo por María. De nuevo una impronta que viene a avalar el modelo de santidad que se propone.

Entre las inspiraciones más difusas las hay de tipo local y general. De estas últimas, dentro de la tradición católica, podemos enumerar la provisión divina de alimento y vestido, propia de personas o grupos elegidos y protegidos por Dios. Por otra parte, el futuro descubrimiento de su cadáver por un pastor, nos recuerda las imágenes sagradas ocultas ante la invasión sarracena y su posterior hallazgo, generalmente por un pastor. Su permanencia en una cueva o depósito durante siglos, hasta el momento propicio para su descubrimiento, conecta con la fe verdadera de aquellos cristianos sometidos y el deseo de mantener su culto en un futuro indeterminado. También la figura del pastor es uno de los iconos católicos que nos remite al Señor que apacienta su rebaño. Más de actualidad en la época era el anuncio de la disputa de sus reliquias por las gentes, cuando el cuerpo fuese descubierto. Poseer una reliquia santa suponía un seguro al que encomendarse: recordemos el traslado de san Juan de la Cruz o el caso de la beata Juana de Cristo, cuyo cuerpo incorrupto fue mutilado incluso en su enterramiento. Todo ello, tendría un fin preestablecido y concreto, la opinión general de la santidad que provocaría María y la devoción que generaría, que debía conducir al objetivo final: una fundación conventual mercedaria calzada.

Un factor, a nuestro juicio importante, es el espacio donde se ubica el eremitorio, la Sierra de Elvira, un lugar en el que los lugareños encontraban restos arqueológicos con bastante frecuencia, incluso en periodos de paro agrícola buscaban "tesoros» en la montaña. El hallazgo de enterramientos, ajuares, urnas cinerarias, restos arquitectónicos y objetos arqueológicos diversos, conectaban el lugar con la antigüedad clásica. Y no solo eso, sino que, a pesar de haber transcurrido más de cien años de los hallazgos del Sacromonte, en este caso, resulta inevitable relacionar los sacromontanos con los elvirianos. Esta circunstancia se ve impulsada si tenemos en cuenta que la ubicación original del beaterio fue justo a los pies de la abadía y que las beatas eligieron ese lugar precisamente por su proximidad. Enlazan así los descubrimientos de Sierra Elvira con el propio discur- so de los orígenes de las beatas, así como con otros elementos comunes tales como la práctica del Vía Crucis, la relación con los canónigos de la abadía, la predilección y propaganda que recibió María de Baltasar de Rienda, etc.

Por otra parte, en cuanto a la fundación, los mercedarios calzados granadinos estaban al corriente de aquellas que, partiendo de beaterios, se habían llevado a cabo en Granada, un número considerable. Además, dentro de la Orden Mercedaria, aunque fuese la rama descalza, existía el precedente de la fundación en 1620 del convento de Fuentes de Andalucía. Una fundación basada en la fama de santidad de la beata Juana de Cristo, beata a la que ya hemos hecho referencia anteriormente. A decir de sus contemporáneos, su vida fue un tanto excéntrica, pero consiguió profesar y morir en olor de santidad, aunque no debemos salir de nuestra ciudad para encontrar un modelo próximo. En Granada era conocido el caso de la beata mercedaria descalza Catalina de Jesús, que giraba en la órbita del convento de Belén. Catalina había muerto en agosto de 1624, siendo enterrada en el altar de la Oración en el Huerto del convento. Tres años más tarde, en 1627, se halló su cuerpo incorrupto, algo que volvió a ocurrir en 1742. Por tanto, no faltaban ejemplos de santidad entre las beatas mercedarias. Otras religiosas estuvieron próximas a los conventos mercedarios descalzos andaluces, no en número elevado, aunque sí hubo profesiones y conventos femeninos que las integraron en sus filas. ${ }^{38}$ Todas estas circunstancias debieron influir en el proyecto granadino.

\section{CONCLUSIONES}

A mediados del siglo XVII, los mercedarios calzados granadinos habían conseguido atraer a la órbita de su Orden a un grupo de mujeres que terminaron profesando como beatas de la misma. Este hecho, en principio, no sucedió de forma espontánea y voluntaria; por el contrario, fue consecuencia de la presión social, hostil a la existencia de mujeres que vivían una religiosidad ajena a la jerarquía del estamento eclesial. La toma de hábito reconocido "normalizaba» la convivencia, aunque sometía a estas mujeres a una regulación de dependencia jerárquica.

Nos encontramos, por tanto, ante una reacción social de rechazo al ejercicio de una libertad individual que debemos contextualizar en su momento histórico, cuando tal libertad ni se encontraba regulada ni era comprendida en amplios sectores sociales, en parte por las connotaciones asociadas a casos de picaresca o marginación. El fruto de la institucionalización de las mujeres que no quisieron o no pudieron profesar como monjas, fue fomentado e instrumentalizado por las órdenes religiosas fundando beaterios. El fin último era establecer las condiciones suficientes para expandir la orden fundando conventos femeninos regulares.

Este fue el caso de los mercedarios calzados granadinos, instalados en la ciudad desde su toma a los musulmanes y con raíces en la misma anteriores a este momento. La estrategia que diseñaron para intentar una fundación conventual

38 Hasta el capítulo mercedario descalzo de Écija en abril de 1616, no se decidió integrar a las beatas como religiosas profesas, siguiendo las normas dictadas por Pío V. 
femenina no difiere mucho, en principio, de las demás órdenes. Tras captar un grupo de beatas para su regla, el intento fundacional debió posponerse por varias razones: los escasos efectivos del grupo, la falta de financiación y la muerte de María de la Concepción, en principio destinada a liderar el proyecto. La singularidad del caso arranca cuando estas circunstancias propician que el eje del mismo se desplace hacia una beata heterodoxa o singular: María de Santa Rosa. Esta mujer mantiene rasgos de beata libre, al trocar la institucionalización por la vida eremita en una cueva de Sierra Elvira. A partir de ahí, los mercedarios granadinos se sirven de lo original del caso para intentar alcanzar varios objetivos: proclamar la superioridad de la Orden Mercedaria sobre las demás, tomando el hábito como símbolo, y proponer un modelo de santidad basado en la figura de la «santa de Sierra Elvira». Para ello, fray Fernando Del Olmo instruye una «información» interna, sin validez eclesial, pero con todas las características formales de estos procedimientos. El objetivo final confeso era fundar un convento femenino mercedario calzado, basándose en la devoción que provocaría el cadáver de María cuando se descubriera.

Toda la crónica se encuentra salpicada de reminiscencias más o menos expresas, conectadas con otros acontecimientos o conceptos a los que se quiere encontrar correspondencia, aunque sea de forma inconsciente para el lector. Antigüedad clásica, cristiandad primitiva, reliquias, mensajes bíblicos subliminares, hechos sobrenaturales, etc. se dan cita con el fin de establecer y afianzar la santidad de María. Una santidad que, como otras muchas, no fue posible. Tampoco la fundación alcanzaría buen puerto. En cambio, quedó el recuerdo festivo para las gentes de Sierra Elvira, un recuerdo que se mantuvo durante siglos.

\section{FUENTES}

Acosta, J. 1871. «La cueva de Sierra Elvira. Tradición granadina». El Liceo de Granada. Revista quincenal de ciencias, literatura y artes 1: 4-9.

Albornoz, D. F. de trad. 1668. Breve relación de la solemnísima fiesta de beatificación de la bienaventurada Rosa de Santa María. Granada: en la Imprenta Real de Baltasar de Bolibar, Impresor del S. Oficio de la Inquisición.

Almaraso García, A. R. [1858]. Traslado de la Vida de la Ven. María de Sta. Rosa: conocida regularmente por la Santa de Sierra Elvira Hermitaña y Solitaria de ella. Era Beata del Orden de María Stma. de la Merced, Redempcion de Cautivos Cristianos de Granada. Mss., Biblioteca de Filosofía y Letras A, Universidad de Granada.

Colección de escritos tocantes a la Orden de la Merced. Madrid, Biblioteca Nacional, Ms. 8293. S. XVII-XVIII.

Colombo, F. Historia general de la Real Militar Orden de Nuestra Sra. De la Merced Redención de Cautivos: desde su milagrosa Fundación hasta nuestros tiempos. Madrid, Biblioteca Nacional, Ms. 4159. S. XVIII.

Esteban, J. de S. "Noticas sobre las tres monjas arriba citadas», en Colección de escritos tocantes... op. cit. Madrid, Biblioteca Nacional, Ms. 8293, 35: 366-375.

Chica Benavides, A. de la 1764. Gazetilla curiosa o Semanero granadino. Ed. Facs. Granada: Albaida.

Henríquez de Jorquera, F. 1987. Anales de Granada: descripción del Reino y Ciudad de Granada, crónica de la reconquista (1482-1492), sucesos de los años 1588 a 1646. Granada: Universidad.

Lorenzo, J. de S. [1709]. Mystica flor granadina, y trinitaria vida de la venerable, y extatica hermana Thomasa del Espíritu Santo, religiosa (...) de Descalços de la Santissima Trinidad Redención de Cautivos; dase una breve noticia de la vida de su hermano (...) Fr.
Joseph de los Santos (...) del mismo Orden. Granada: en la Imprenta de la SS. Trinidad, por Antonio de Torrubia.

Medina Conde Herrera, C. 1760. Granada abierta a Dios en la fundación de la casa de Sta. María Egypciaca, de Madres Recogidas. Historia desde su origen hasta el presente. Vidas de sus fundadores, y rectoras: con el Compendio de el Gobierno del Regimiento. Granada: por Antonio Henriquez y Santa María.

Montalvo, T. de 1698. Vida Prodigiosa y Heroycas Virtudes del V.P. Fr. Francisco Molinero, Religioso Lego Descalzo de N.S.P.S. Francisco, hijo de la santa Provincia de S. Pedro de Alcantara, sita en los Reinos de Granada, y de Murcia. Granada: por Antonio de Torrubia.

Montalvo, T. de 1701. Práctica política y económica de expósitos. Granada: en la Imprenta de la Santissima Trinidad, por Antonio de Torrubia.

Natividad, J. de la 1697. Coronada historia, descripción lavreada, de el misterioso genesis, y principio Augufto de el eximio portento de la Gracia, y admiración de el Arte de la milagrofa Imagen de Maria Santissima de Gracia. Granada: Francisco de Ochoa.

Olmo, F. del (OM)a. «Cronología topográfica sinóptica del convento mercedario de Granada, en que trata de su fundación, etc.» (sic), en Colección de escritos tocantes... op. cit., Madrid, Biblioteca Nacional, Ms. 8293, 2: 1-22.

Olmo, F. del (OM)b. «Memorias de la fundación y antigüedad de este convento de Granada, del Real y Militar Orden de Nuestra Señora de la Merced Redención de Cautivos», en Colección de escritos tocantes... op. cit., Madrid, Biblioteca Nacional, Ms. 8293, 3: 25-27.

Olmo, F. del (OM)c. «Profesiones hechas en el convento mercedario de Granada desde 1527 a 1634 », en Colección de escritos tocantes... op. cit., Madrid, Biblioteca Nacional, Ms. 8293, 11: 86-90.

Olmo, F. del (OM)d. "Memoria de Sor Jacinta de Santa María, mercedaria», en Colección de escritos tocantes... op. cit., Madrid, Biblioteca Nacional, Ms. 8293, 32: 342-345 v.

Olmo, F. del (OM)e. «Noticia de la Venerable Heremita María de Santa Rosa, solitaria de la Sierra de Elvira», en Colección de escritos tocantes... op. cit., Madrid, Biblioteca Nacional, Ms. 8293, 34: 354-365.

Olmo, F. del (OM)f. "Memoria de sor Juliana de de Jesús», en Colección de escritos tocantes... op. cit., Madrid, Biblioteca Nacional, Ms. 8293, 35: 366-375.

Olmo, F. del (OM)g. "Sucesos de la vida de María de Santa Rosa y cartas sobre situaciones místicas», en Colección de escritos tocantes... op. cit., Madrid, Biblioteca Nacional, Ms. 8293, 37: 384-391.

Ortega y Cotes, I. J. de [1754]. Discurso histórico-legal sobre varios instrumentos, que se deben compulsar en el proceso compusorial de la beatificación de la Ve. Señora Infanta Da . Sancha Alfonso, religiosa del Orden de Santiago (...). [S.I., s.n.].

Papeles varios. Madrid, Biblioteca Nacional, Ms. 3456. S. XVIII.

Papeles varios, manuscritos e impresos, referentes a los Mercedarios y a los Carmelitas Descalzos. Madrid, Biblioteca Nacional, Ms. 8730. Ss. XVII-XVIII.

Relación breve de las fiestas que el Real Convento de Santa Cruz de Granada dispuso y hizo en la beatificación de la venerable y esclarecida virgen, la bienaventurada Rosa de Santa María. Granada: por Baltasar de Bolibar, 1668.

Rienda, B. de 1662. Carta exhortando a la predicación del Evangelio. Granada: [s.n.].

Rienda, B. de 1662. Carta exhortatoria que escrive el licenciado Baltasar de Rienda (...) a un amigo suyo beneficiado de cierta iglesia del arçobispado de Granada exhortándole a la predicación del S. Euangelio a sus feligreses y aplicación al confesionario (...). Granada: en la Imprenta Real, por Baltasar de Bolibar.

Rienda, B. de 1680 . Tesoro espiritual de enseñanzas, y ejercicios muy meritorios (...) para (...) vivir bien y morir bien. Granada: [s.n.].

Rosiqué, P. 1695. Sermón, en que se da noticia de la vida del admirable, virtudes heroycas, y preciosa muerte del Venerable Padre Fray Francisco Molinero (...) murió con fama de santidad en el muy Religioso Convento de S. Antonio de Padua de esta ciudad de Granada a 16 de mayo de 1695. Granada: Imprenta de la Santissima Trinidad por Antonio de Torrubia.

Ruiz de Mesa, M. 1674. Vida y obras del venerable maestro Ivan de Avila, predicador apostolico de Andalvcia. Madrid: por Antonio Gonçalez de Reyes. 
Sánchez de Feria y Morales, B. 1782. Memorias sagradas del yermo de Córdoba, desde su inmemorial principio hasta el presente, recogidas y ordenadas por D. Bartolomé Sánchez de Feria y Morales. Córdoba: en la oficina de Don Juan Rodríguez de la Torre.

Serrano, D. 1769. Vida de la Azucena Rosa, Mercedaria, la V. María de Santa Rosa ó por otro nombre la Santa de Sierra Elvira, Beata de la Orden de María Stima. de la Merced, Redención de Cautivos de la Ciudad de Granada escrita por el R. P. M. F. Diego Serrano, Religioso del R. Convento de la misma Orden de dicha ciudad. Año de 1769. Biblioteca del Hospital Real de Granada, Universidad de Granada: MS-2-055 (29). DIGIBUG: Repositorio Institucional de la Universidad de Granada: <http://hdl.handle.net/10481/16698>

Villarreal, F. 1888. "La cueva de Sierra Elvira», en El Libro de las Tradiciones Granadinas. Granada: [s.n.].

\section{REFERENCIAS BIBLIOGRÁFICAS}

Alabrús Iglesias, Rosa María. 2016. «El éxito y el fracaso en los procesos hacia la santidad femenina». En Identidades y fronteras culturales en el mundo ibérico en la Edad Moderna, dir. José Luis Beltrán Moya, 169-178. Barcelona: Universitat Autonoma.

Aranda Doncel, Juan. 2002. «Un proyecto frustrado en la villa cordobesa de Palma del Río en el siglo XVII: la fundación de los Mercedarios». Boletín de la Real Academia de Córdoba de Ciencias, Bellas Letras y Nobles Artes 141: 183-192.

Aranda Doncel, Juan. 2006. «Fundaciones conventuales masculinas en la diócesis de Córdoba durante el siglo XVII: los proyectos fallidos». En Estudios en homenaje al profesor José Smolka Clares, 187-199. Granada: Universidad.

Arias Saavedra y Alías, Inmaculada, Esther Jiménez Pablo y Miguel Luis López-Guadalupe Muñoz, eds. 2018. Subir a los altares: modelos de santidad en la Monarquía Hispánica (siglos XVI-XVIII). Granada: Universidad.

Atienza López, Ángela. 2012. «Los que fracasaron: fundaciones y fundadores frustrados. La otra cara de la expansión conventual en la España moderna» En Iglesia, poder y fortuna. Clero y movilidad social en la España moderna, ed. Enrique Soria Mesa y Antonio José Díaz Rodríguez, 89-114. Granada: Comares.

Atienza López, Ángela. 2014. «Fundaciones frustradas y efímeras en la España moderna. Memoria de los conventos franciscanos que no pudieron ser». Cuadernos de Historia Moderna 39: 189-219. https://doi.org/10.5209/rev_CHMO.2014.v39.45847

Ceballos Guerrero, Antonio. 2015. «Ellas y ellos. Un análisis de la fundación del convento de santo Tomás de Villanueva de Granada en clave de género». Chronica Nova. Revista de Historia Moderna de la Universidad de Granada 41: 145-168.

Ceballos Guerrero, Antonio. 2016. Feminidad, religión y poder local. Una aproximación a la génesis y evolución del convento de santo Tomás de Villanueva de Granada (siglos XVII y XVIII). Granada: Universidad de Granada. http://hdl.handle.net/10481/42411

Cortés Peña, Antonio Luis. 2006. «Intentos de fundaciones religiosas en el reinado de Carlos III». En Poder civil, iglesia y sociedad en la Edad Moderna, ed. Antonio Luis Cortés Peña, 399-412. Granada: Universidad.

Fernández García, María de los Ángeles. 1989. Inquisición, comportamiento y mentalidad en el Reino de Granada (1600-1700). Granada: María de los Ángeles Fernández.

Gallardo Téllez, Eduardo. 2000. «Fundaciones religiosas frustradas en Vélez-Málaga durante los siglos XVII y XVIII». Isla de Arriarán 16: 55-67.

Gallego Burín, Antonio. 1982. Granada: Guía artística e histórica de la ciudad. Granada: Don Quijote.

García Bernal, José. 2007. «Santidad femenina y devoción barroca: el recibimiento del cuerpo incorrupto de la Venerable Madre María de la Antigua en Marchena». En La mujer en la historia de Marchena: Actas de las XI Jornadas sobre Historia de Marchena, 77-119. Marchena (Sevilla): Ayuntamiento.
García Bernal, José. 2012. «La narrativa fundacional y la escritura de la historia en los mercedarios descalzos de Andalucía: el Convento de la Almoraima». En Iglesia memorable. Crónicas, historias, escritos... a la mayor gloria. Siglos XVI-XVIII, ed. Ángela Atienza López, 205-229. Madrid: Silex.

García Valverde, María Luisa. 2017. «Beatas dominicas en Granada: el Beaterio de Santa Catalina de Sena». En Clarisas y dominicas. Modelos de implantación, filiación, promoción y devoción en la Península Ibérica, Cerdeña Nápoles y Sicilia, ed. Gemma Colesanti, Blanca Garí y Nuria Jornet-Benito, 269-289. Firenze: University Press.

Giordano, María Laura. 2007. «Al borde del abismo: 'falsas santas' e 'ilusas' madrileñas en la vigilia de 1640». Historia social 57: 75-97.

González Fernández, Francisco Javier. 2016. La beata Juana de Cristo (1586-1616) y el establecimiento de la Orden de la Merced Descalza en Fuentes de Andalucía. Fuentes de Andalucía (Sevilla): Ayuntamiento.

Instituto Histórico de la Orden de la Merced. 1997. La Orden de Santa María de la Merced (1218-1992): Síntesis histórica. Roma: Instituto Histórico de la Orden de la Merced.

López-Guadalupe Muñoz, Miguel Luis. 2015. «Sublimación espiritual y atracción social: la descalcez femenina en la Granada del siglo XVII». Librosdelacorte.es monográfico 3 (7): 121-137

Lozano Navarro, Julián José. 2018. «Entre jesuitas y beatas. La percepción de la santidad en el colegio de la Compañía de Jesús en Marchena (siglos XVII y XVIII)». En Subir a los altares: modelos de santidad en la Monarquía Hispánica (siglos XVI-XVIII), ed. Inmaculada Arias Saavedra y Alías, Esther Jiménez Pablo y Miguel Luis López-Guadalupe Muñoz, 51-77. Granada: Universidad.

Martínez Millán, José. 2018. «El cambio de modelo de santidad durante la segunda mitad del siglo XVII». En Subir a los altares: modelos de santidad en la Monarquía Hispánica (siglos XVI-XVIII), ed. Inmaculada Arias Saavedra y Alías, Esther Jiménez Pablo y Miguel Luis López-Guadalupe Muñoz, 79-108. Granada: Universidad.

Martínez Ruiz, Emilia. 1994. "Sobre la vida y la muerte de la Hermana Lorenza de San Pascual (1655-1721)». Revista del Centro de Estudios Históricos de Granada y su Reino 8: 217-272.

Montes González, Francisco. 2010. «Rosa en su celestial paraíso. Una fiesta limeña en la Granada barroca». Cuadernos de Arte de la Universidad de Granada 41: 149-168.

Morrás, María. 2015. "Ser santa y mujer (península ibérica, siglos XV-XVII)». Medievalia 18 (2): 9-24. https://doi.org/10.5565/rev/ medievalia.338

Morte Acín, Ana. 2012. "Mujeres ejemplares en los modelos de santidad barrocos». En De la tierra al cielo: líneas recientes de investigación en historia moderna, ed. Eliseo Serrano Martín, v. 2, 935-948. Zaragoza: Instituto «Fernando el Católico».

Morte Acín, Ana. 2015. «Tradiciones y pervivencias medievales en los modelos de santidad femenina en la Edad Moderna». Medievalia 18 (8): 297-323. https://doi.org/10.5565/rev/medievalia.350

Rivero Rodríguez, Manuel. 2018. "Los santos los crea el pueblo: el Inquisidor García de Trasmiera y la venerable sor Orsola Benincasa». En Subir a los altares: modelos de santidad en la Monarquía Hispánica (siglos XVI-XVIII), ed. Inmaculada Arias Saavedra y Alías, Esther Jiménez Pablo y Miguel Luis López-Guadalupe Muñoz, 401422. Granada: Universidad.

Serrano Martín, Eliseo 2018. "Santos que quedaron en el camino. Vidas religiosas y procesos hacia la santidad en la Edad Moderna. Una aproximación con ejemplos aragoneses». En Subir a los altares: modelos de santidad en la Monarquía Hispánica (siglos XVI-XVIII), ed. Inmaculada Arias Saavedra y Alías, Esther Jiménez Pablo y Miguel Luis López-Guadalupe Muñoz, 155-185. Granada: Universidad.

Valencina, Ambrosio de. 1906-1908. Reseña histórica de la Provincia Capuchina de Andalucía. Varones ilustres en ciencia y virtud que han florecido en ella desde su fundación hasta el presente. Sevilla: Imprenta de la Divina Pastora. 